\title{
Analisis Kandungan Nutrisi Pakan Ternak Fermentasi Berbahan Dasar Daun Jati (Tektona grandis) dengan Lama Fermentasi yang Berbeda
}

\author{
Wulandari ${ }^{1}$, Santi ${ }^{2}$, Andi Tenri Bau Astuti Mahmud ${ }^{3}$

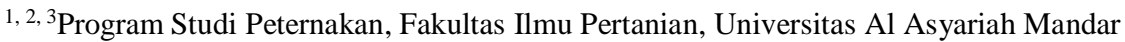 \\ Email: wulandari170198@gmail.com; santipeternakan@gmail.com
}

\begin{abstract}
Tujuan penelitian ini bertujuan untuk mengetahui lama penyimpanan terbaik untuk mendapatkan silase daun jati dengan kandungan nutrisi yang lebih optimal, yang dilakukan pada bulan Januari-Maret 2021 di Desa Bonra Kec. Mapilli Kab. Polewali Mandar dan dilanjutkan dengan analisis kandungan nutrisi di Laboratorium Kimia Pakan Universitas Hasanuddin, Makassar. Pada penelitian ini Rancangan yang digunakan adalah Rancangan Acak Lengkap (RAL) dengan 5 perlakuan dan 3 ulangan sehingga menghasilkan 15 kombinasi perlakuan. Yang masing-masing dibagi menjadi perlakuan P0 (0 minggu penyimpanan), P1(2 minggu penyimpanan ), P2 (4 minggu penyimpanan), P3 (6 minggu penyimpanan) dan P4 (8 minggu penyimpanan). Hasil uji duncan menunjukkan dengan perlakuan lama penyimpanan, terjadi perbedaan nyata terhadap kadar serat kasar dan bahan kering, namun tidak berbeda nyata $(\mathrm{P}<0,05)$ terhadap kadar lemak kasar, protein kasar dan BETN namun terjadi fluktuasi. Pada penelitian ini diketahui bahwa penyimpanan terbaik untuk mendapatkan kandungan nutrisi optimal pada pakan fermentasi berbahan dasar daun jati yaitu pada perlakuan P1 (penyimpanan 2 minggu) dengan rataan kandungan serat kasar (18.28\%), lemak kasar (6.17\%), protein kasar (10.19\%), BETN $(57.47 \%)$ dan bahan kering (49.83).
\end{abstract}

Keywords : Silase; Daun Jati; Fermentasi; Pakan Ternak; Lama Penyimpanan

\section{Pendahuluan}

Usaha peternakan kambing, pakan memegang peranan utama. Biaya pakan merupakan biaya terbesar yang harus dikeluarkan peternak, yaitu sekitar $60 \%-70 \%$ dari keseluruhan biaya. Ketersediaan pakan ternak, baik secara kualitas maupun kuantitas terkadang dikeluhkan oleh beberapa peternak terlebih saat memasuki musim kemarau. Hal tersebut disebabkan pada musim kemarau produktivitas hijauan rendah dengan kadar serat kasar yang tinggi.

Kelangkaan bahan pakan pada musim kemarau dapat diimbangi dengan pengawetan bahan pakan pada musim hujan. Salah satu bentuk pengawetan bahan pakan yaitu fermentasi. Pengawetan tersebut merupakan pengawetan anaerob yang memanfaatkan bakteri asam laktat dengan tetap mempertahankan kualitas bahan pakan hasil fermentasi. Katerbatasan hijauan pakan sebagai bahan pembuatan pakan silase menjadi permasalahan dalam pengawetan pakan. Hal tersebut disebabkan karena lahan untuk hijauan pakan telah dialih fungsikan. Oleh karena itu, dibutuhkan tanaman lain yang lebih produktif dan belum dimanfaatkan dengan baik.

Tanaman Jati (Tektona grandis) merupakan tanaman yang ditanam pada lahan hutan. Pertumbuhan tanaman ini tergolong cepat dan tidak memerlukan teknik penanaman yang sulit serta memiliki nilai ekonomis yang tinggi. Cara untuk mendapatkan daun tanaman Jati yaitu dengan melakukan pemangkasan secara rutin yang mana biasa dilakukan di awal musim penghujan. Limbah hasil pemangkasan ranting tanaman Jati (Tektona grandis) sangat potensial untuk dimanfaatkan menjadi pakan ternak (Muwakhid, 2011).

Kendala yang dihadapi pada pemanfaatan tanaman Jati yaitu kadar protein kasar yang rendah berkisar 5,05\% begitupun pada kadar serat kasarnya yaitu 31,02\%
(Agustono at al., 2017). Hal tersebut mengakibatkan perlu dilakukan pengkombinasian dengan bahan pakan yang bernutrisi tinggi. Salah satu jenis tanaman yang dapat mengimbanginya yaitu tanaman Gamal (Gliricidia maculata). Kadar nutrisi yang terdapat pada daun Gamal yaitu serat kasar 15,78\% dan protein kasar 24,68\% (Syahrir, 2016). Selain dengan penambahan daun Gamal cara lain yang dapat dilakukan untuk memperbaiki kandungan nutrisi pakan yaitu dengan proses fermentasi.

Manfaat lain dari perlakuan fermentasi yaitu dapat meningkatkan platabilitas serta daya simpan pakan. Ada beberapa hal yang dapat mempengaruhi perombakan zat nutrisi pada proses fermentasi salah satunya yaitu lama penyimpanan. Hal ini yang menjadi alasan dilakukannya penelitian untuk mengetahui keterkaitan antara lama fermentasi terhadap kualitas nutrisi silase berbahan dasar daun Jati. Adapun rumusan masalah pada penelitian ini:

a. Bagaimana kandungan nutrisi pakan fermentasi berbahan dasar daun Jati dengan perlakuan lama penyimpanan yang berbeda?

b. Berapa lama waktu penyimpanan terbaik yang seharusnya digunakan untuk mendapatkan kandungan nutrisi pakan fermentas daun Jati terbaik sebagai pakan ternak?

Penelitian ini bertujuan untuk :

a. Mengetahui lama waktu penyimpanan yang terbaik untuk mendapatkan nutrisi pakan yang optimal.

b. Sebagai acuan untuk peternak dalam pemanfaatan silase berbahan dasar Jati sebagai pakan ternak.

Manfaat dilakuakannya penelitian ini adalah :

a. Dapat menjadi bahan informasi bagi peternak dalam pemanfaatan tanaman Jati sebagai pakan ternak ruminansia melalui proses fermentasi. 
b. Dapat membantu memecahkan permasalahan mengenai ketersediaan bahan pakan yang terbatas terutama pada musim kemarau.

c. Sebagai bahan untuk menambah pengetahuan dan melakukan penelitian lebih mendalam.

\section{Metodologi}

Penelitian ini dilakukan pada bulan Januari - Maret 2021, bertempat di Desa Bonra Kecamatan Mapilli Kabupaten Polewali Mandar dan dilanjutkan dengan uji kandungan nutrisi di Laboratorium Kimia Pakan Fakultas Peternakan Universitas Hasanuddin Makassar.

Alat yang digunakan yaitu terpal, kantong plastik, pisau/parang, timbangan, tali rapiah, ember, alat untuk analisis proksimat (labu kedjdahl, desikator, oven, erlenmeyer, kertas saring, kapas).

Bahan yang digunakan adalah daun Jati, daun Gamal, molases/gula, dedak, air dan bahan untuk analisis proksimat (Selenium, $\mathrm{H}_{2} \mathrm{SO}_{4}, \mathrm{NaOH}, \mathrm{HCl}, \mathrm{H}_{2} \mathrm{BO}_{3}$ )

Adapun prosedur penelitian yaitu : Campurkan semua bahan yang diperlukan dalam pembuatan silase daun Jati dengan takaran sesuai formulasi ransum yang terdapat pada Tabel 1. Setelah semuanya tercampur rata timbang sebanyak $2 \mathrm{~kg}$ dan masukkan ke dalam kantong plastik untuk selanjutnya diikat dan di simpan dengan waktu sesuai perlakuan masing-masing.

Tabel 1. Komposisi Pakan Fermentasi Berbahan Dasar Daun Jati

\begin{tabular}{ccc}
\hline No & Bahan & Komposisi (\%) \\
\hline 1 & Dedak Padi & 8,5 \\
2 & Daun Jati & 50 \\
3 & Daun Gamal & 40 \\
4 & Molases & 1,5 \\
\hline & Total & 100 \\
\hline
\end{tabular}

Penelitian ini menggunakan Rancangan Acak Lengkap (RAL)dengan 5 perlakuan dan 3 ulangan sehingga menghasilkan 15 kombinasi perlakuan secara keseluruhan, dengan unit percobaan sebagai berikut :

P0: Penyimpanan 0 minggu (kontrol)

P1: Penyimpanan 2 minggu

P2: Penyimpanan 4

P3: Penyimpanan 6

P4: Penyimpanan 8

Hasil yang didapatkan dilanjutkan dengan uji Duncan apabila nilainya menunjukkan perbedaan sari tiap perlakuan. Analisis statistik menggunakan software SPSS16.0

\section{Hasil}

Dari hasil penelitian, diperoleh rataan kadar nutrisi (bahan kering, lemak kasar, serat kasar, protein kasar dan BETN) pakan fermentasi berbahan dasar daun Jati dapat dilihat pada Tabel 2.

Tabel 2. Nilai rataan kadar nutrisi pakan fermentasi berbahan dasar daun Jati

\begin{tabular}{cccccc}
\hline \multirow{2}{*}{ Parameter } & \multicolumn{5}{c}{ Perlakuan } \\
\cline { 2 - 6 } & P0 & P1 & P2 & P3 & $31.82^{\mathrm{d}} \pm 5.43$ \\
\hline Bahan Kering (g) & $55.03^{\mathrm{a}} \pm 5.00$ & $49.83^{\mathrm{ab}} \pm 5.03$ & $43.11^{\mathrm{bc}} \pm 2.85$ & $36.49^{\mathrm{cd}} \pm 3.03$ & $10.15 \pm 0.60$ \\
Protein Kasar $(\mathrm{g})$ & $9.66 \pm 0.53$ & $10.19 \pm 0.31$ & $10.26 \pm 0.51$ & $5.91 \pm 0.56$ & $9.98 \pm 0.39$ \\
Lemak Kasar $(\mathrm{g})$ & $5.07 \pm 0.57$ & $6.17 \pm 0.71$ & $5.52 \pm 0.74$ & $18.51^{\mathrm{bc}} \pm 0.39$ & $6.19 \pm 0.67$ \\
Serat kasar $(\mathrm{g})$ & $20.91^{\mathrm{a}} \pm 0.79$ & $19.28^{\mathrm{b}} \pm 0.25$ & $18.76^{\mathrm{bc}} \pm 0.24$ & $57,73 \pm 1.10$ & $18.08^{\mathrm{c}} \pm 0.20$ \\
BETN $(\mathrm{g})$ & $57.51 \pm 2.14$ & $57.47 \pm 0.25$ & $57.73 \pm 1.92$ & $58.30 \pm 1.12$ \\
\hline
\end{tabular}

Ket: Notasi huruf berbeda pada baris yang sama menunjukkan pengaruh nyata $(\mathrm{P}<0,05)$; P0 = Fermentasi pakan selama 0 minggu; P1 = Fermentasi pakan selama 2 minggu; P2 = Fermentasi pakan selama 4 minggu; P3 = Fermentasi pakan selama 6 minggu; P4 = Fermentasi pakan selama 8 minggu.

\section{Kadar Bahan Kering}

Dari hasil penelitian yang dilakukan menunjukkan bahwa lama penyimpanan pada pakan silase berbahan dasar daun Jati berbeda nyata terhadap persentase kadar bahan kering. Lama penyimpanan dan kandungan bahan kering berkorelasi negatife, yaitu semakin lama proses penyimpanan maka kandungan bahan kering akan semakin berkurang. Analisis sidik ragam menunjukkan kandungan bahan kering tertinggi yaitu pada penyimpanan 0 minggu dengan nilai 55.03 dan yang terendah pada penyimpanan 8 minggu yaitu 31.82. P0 (control) tidak bebeda nyata terhadap P1. Perlakuan P1 tidak berbeda nyata terhadap P0 dan P2. P2 memiliki nilai yang berbeda nyata dengan P4 dan P0. P3 berbeda nyata terhadap P0 dan P1. Sedangkan P4 menunjukkan nilai yang berbeda nyata dengan P0, P1 dan P2.
Penurunan kadar bahan kering yang terjadi diakibatkan oleh kandungan air yang keluar dari substrat selama proses fermentasi. Dengan demikian, lamanya proses fermentasi mempengaruhi tingkat penurunan bahan kering dalam substrat. Surono et al., (2003) bahwa proses fermentasi mempengaruhi turunnya kadar bahan kering. Ini diakibatkan karena terjadinya perombakan nutrisi dan peningkatan kadar air. (Amaliah et al., 2019) menyatakan, pada proses fermentasi penguraian nutrisi akan terjadi dan menyebabkan peningkatan kadar asam laktat dan kadar air.

Penurunan bahan kering yang paling signifikan terjadi pada penyimpanan $0-4 \quad-4$ minggu yang mengindikasikan bahwa aktifitas mikroorganisme lebih aktif jika dibandingkan pada penyimpanan $6-8$ minggu. Pada Gambar 1 dapat terlihat penurunan bahan kering pada tiap perlakuan . 


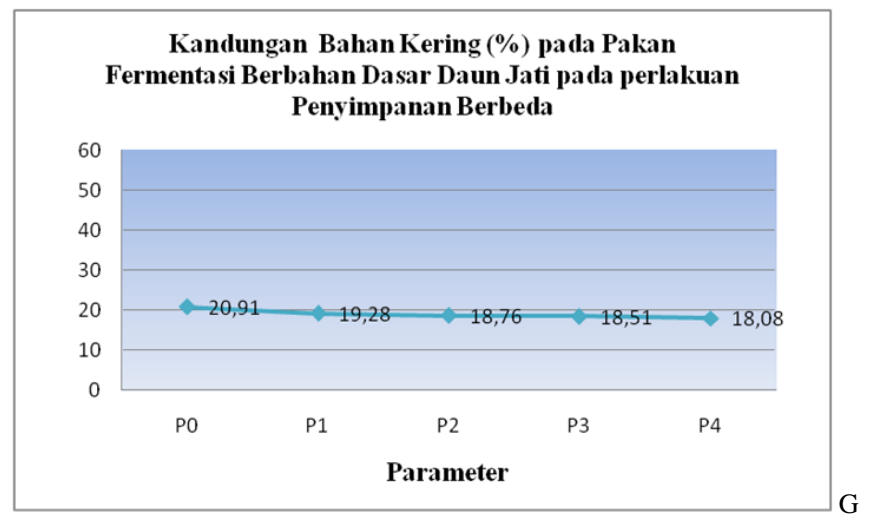

Gambar 1. Grafik Kadar Bahan Kering pada Tiap Perlakuan

\section{Kadar Lemak Kasar}

Rataan kadar lemak kasar yang diperoleh dari pakan fermentasi berbahan dasar daun Jati dengan lama penyimpanan berbeda berkisar antara 5.07 sampai dengan 6.19. Kandungan lemak kasar yang dihasilkan berbanding terbalik terbalik dengan bahan kering. Berdasarkan analisis sidik ragam, kadar lemak kasar mengalami fluktuasi seiring berjalannya waktu fermentasi. Terjadi peningkatan kandungan lemak kasar pada penyimpanan 2 minggu dan pada penyimpanan 4 minggu mangalami penurunan. Namun pada penyimpanan 6 dan 8 minggu kembali terjadi peningkatan. Kadar lemak kasar tertinggi didapat pada penyimpanan 8 minggu dan yang terendah pada penyimpanan 0 minggu. Hal ini kemungkinan disebabkan karena aktivitas mikroba dalam merombak bahan organik seperti karbohidrat menjadi ikatan yang lebih sederhana untuk dimanfaatkan dalam berkembangbiak. Hasil dari perombakan karbohidrat ini akan menghasilkan asam lemak sehingga dalam pakan yang difermentasi terjadi peningkatan kadar lemak.

Adanya peningkatan kadar lemak kasar menunjukkan adanya sintesis asam lemak dalam substrat. Hafizh (2016) menyatakan bahwa terjadi peningkatan kadar lemak kasar pada pakan komplit berbahan dasar ampas sagu yang disebabkan karena terjadinya sintesis asam lemak. Peningkatan nilai kadar lemak kasar dihasilkan dari proses metabolisme mikroorganisme yang terdapat pada substrat (Yunianta dan Hartatik 2015). Pada Gambar 2. dapat dilihat perubahan kandungan lemak kasar pada perlakuan P0 sampai P4.

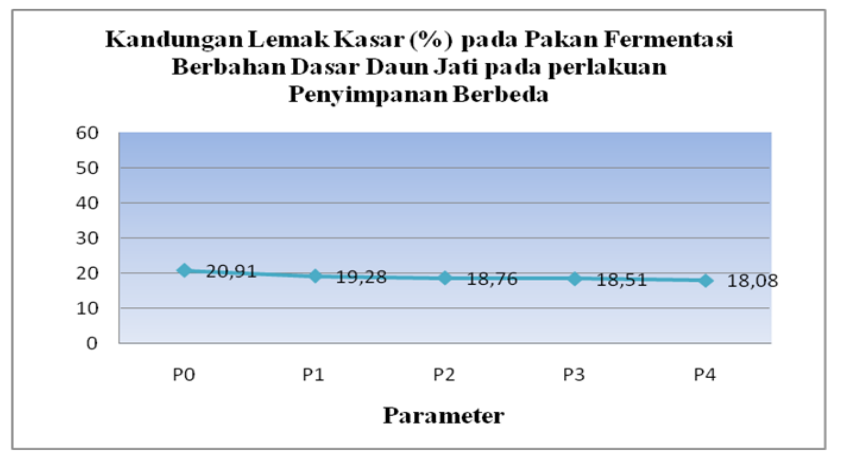

Gambar 2. Grafik Kadar Lemak Kasar pada Tiap Perlakuan

\section{Kadar Protein Kasar}

Hasil analisis sidik ragam menunjukkan peningkatan kadar protein pakan setelah difermentasi bila dibandingkan dengan tanpa proses fermentasi. Aro (2008) menyatakan, proses fermentasi meningkatkan kadar protein kasar pada suatu bahan. Pembedaan lama penyimpanan pakan fermentasi berbahan dasar daun jati menunjukkan niail yang tidak berbeda secara nyata terhadap kadar Protein kasar. Pada Tabel 2. dapat dilihat terjadinya peningkatan kadar protein kasar pada perlakuan P1 dan P2 dan kembali terjadi penurunan pada perlakuan P3 hingga P4. Kandaungan Protein kasar tertinggi didapatkan pada perlakuan P2 (penyimpanan selama 4 minggu) dengan nilai 10.26 diikuti oleh perlakuan P1 (penyimpanan 2 minggu) yaitu 10.19, selanjutnya diikuti oleh perlakuan P3 (peyimpanan 6 minggu) yang nilainya 10.15 , kemudian perlakuan P4 (penyimpanan 8 minggu) dengan nilai 9.98 selanjutnya dengan nilai kadar protein kasar terendah yaitu pada perlakuan P0 (penyimpanan 0 minggu) yang nilainya 9.66.

Peningkatan kadar protein kasar dimulai pada penyimpanan 2 sampai 4 minggu. Hal ini menjukkan terjadinya peningkatan perkembangbiakan mikroorganisme pada minggu-minggu tersebut, yang berarti mikroorganisme dapat merombak lebih banyak nutrisi serta mengubah komponen-komponen dari tubuhnya yang kemudian dapat menimbulkan terjadinya peningjatan protein kasart. Agustono et al., (2010) menyatakan, pada proses fermentasi biomassa mikroba mengalami peningkatan yang mengakibatkan meningkatnya kandungan protein kasar.

Kandungan Protein kasar ini berkurang pada penyimpanan minggu ke 6 dan 8 . Hal tersebut terjadi karena mikroba yang terdapat dalam substar berada pada fase stasioner atau fase pertumbuhan nol. Fardiaz (1992) menyatakan bahwa laju pertumbuhan mikroba akan terus menurun hingga mencapai nilai nol (fase stasioner) setelah mencapai fase eksponensial. Fase ini merupakan fase dimana jumlah sel yang hidup dan yang mati sama atau konstan. Lebih lanjut Hamdat (2010) menyatakan, meskipun pada fase ini tidak terjadi pertumbuhan, fungsi sel seperti metabolisme tetap berjalan, sehingga mikroba yang masih hidup menggunakan zat makanan yang ada pada substrat untuk tumbuh yang menyebabkan zat makanan akan semakin berkurang.

Penurunan dan peningkatan kadar protein pada tiap perlakuan dapat dilihat pada Gambar 3.

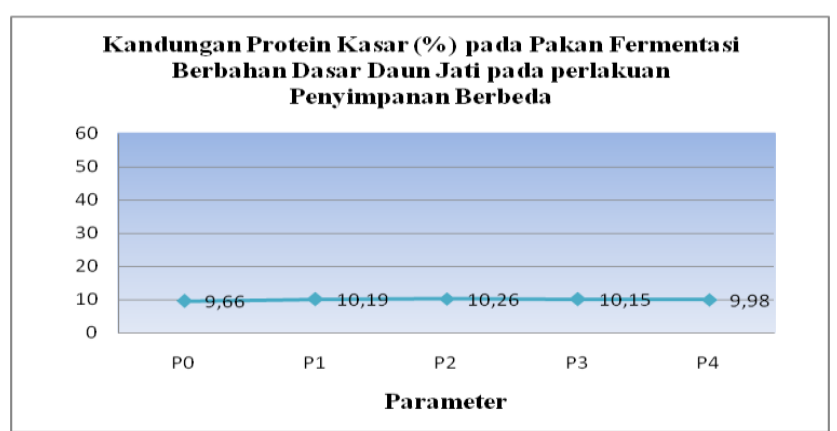

Gambar 3. Grafik Kadar Protein Kasar pada Tiap Perlakuan 


\section{Kadar Serat Kasar}

Berdasarkan Tabel 2. rataan kandungan serat kasar semakin menurun dengan bertambahnya waktu fermentasi. Tingkat kandungan serat kasar pada pakan fermentasi berbahan dasar daun Jati yang tertinggi adalah pada perlakuan P0 (0 minggu peyimpanan) yaitu 20.91 dan yang terendah yaitu pada perlakuan $\mathrm{P} 4$ (8 minggu penyimpanan) dengan kandungan serat kasar 18.08. Dari analisis sidik ragam diketahui bahwa perlakuan pembedaan peyimpanan pakan fermentase berpengaruh terhadap kadar serat kasar. Berdasarkan uji duncan, Perlakuan P0 (penyimpanan 0 minggu) berbeda nyata terhadap semua perlakuan lain. Perlakuan P1 tidak berbeda nyata dengan perlakuan P2 dan P3. Perlakuan P2 dan P3 tidak berbeda nyata terhadap perlakuan P1 dan P4. Perlakuan P4 berbeda nyata terhadap perlakuan P0 dan P1.

Tinggi rendahnya bahan organik pakan kemungkinan terjadi karena pemecahan kandungan pada susbsrtat oleh mikroorganisme untuk memudahkannya dalam mencerna bahan organik. Lama proses penyimpanan berbanding lurus dengan berkurangnya kadar serat kasar pada pakan. Hal ini disebabkan oleh aktifitas mikroba untuk mendegradasi substrat dan menghasilkan enzim yang digunakan untuk memecah ikatan kompleks dan menghasilkan ikatan yang lebih sederhana. Rohmawati et al., (2015) menyatakan bahwa terdapat selulosa, lignin dan hemiselulosa pada Serat kasar, dimana ketiga bahan tersebut digunakan mikroba dalam melakukan pertumbuhannya. Sehingga semakin lama waktu fermentasi maka mikroba memiliki lebih banyak waktu untuk mendekomposit bahan yang mengakibatkan penurunan biomasa nutrisi (Zheng et al., 2011). Pada Gambar 4. dapat terlihat penurunan yang terjadi pada kadar serat kasar pakan fermentasi pada tiap perlakuan.

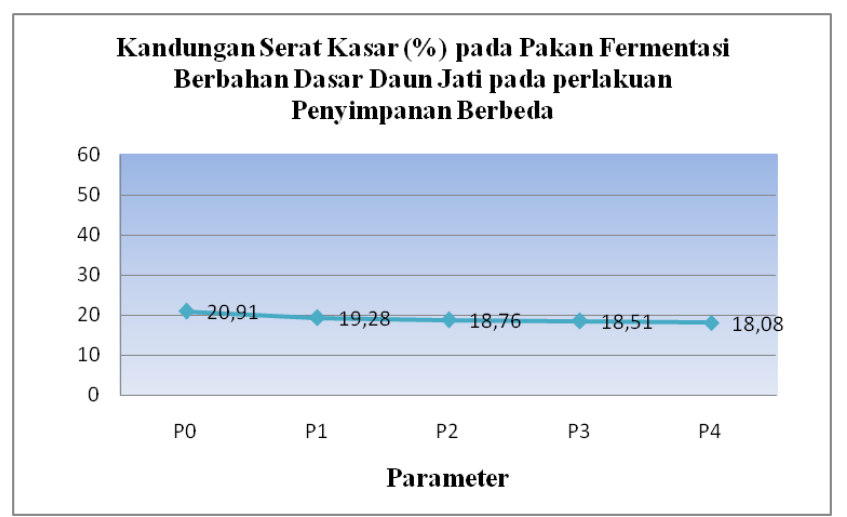

Gambar 4. Grafik Kadar Serat Kasar pada Tiap Perlakuan

\section{Kadar BETN}

Menurut analisis sidik ragam pakan fermentasi berbahan dasar daun Jati dengan lama penyimpanan berbeda tidak bepengaruh signifikan $(\mathrm{P}>0.05)$ terhadap peningkatan kadar BETN pakan. Nilai rataan tertinggi didapaatkan pada perlakuan $\mathrm{P} 4$ (penyimpanan 8 minggu) dengan nilai 58.30 dan yang terendah yaitu pada perlakuan P1 (penyimpanan 2 minggu) yaitu 57.47. Kadar BETN mengalami fluktuasi seiring lamanya proses fermentasi. Pada perlakuan P1 terjadi penurunan kadar bahan BETN dari sebelum difermentasi. Penurunan ini terjadi dikarenakan oleh degradasi yang dilakuakan mikroorganisme terhadap komponen BETN seperti karbohidrat yang merupakan bahan makanan dari mikroba. Anwar (2008) menyatakan bahwa kadar BETN berkurang karena dijadikan bahan makanan mikroba untuk berkembangbiak.

Namun pada perlakuan P2, P3 dan P4 terjadi peningkatan kadar BETN. Hal ini kemungkinan disebabkan oleh semakin lama proses penyimpanan akan meningkatkan jumlah mikroorganisme. Dengan terjadinya peningkatan jumlah mikroorganisme maka semakin meningkat pula jumlah komponen senyawa kompleks yang dapat dirombak. Tilman et al., (1998) menyatakan bahwa adanya peningkatan kadar BETN pada substrat akan menurunkan kadar serat kasarnya. Sutardi (2006) yang menyatakan bahwa kadar BETN sangat dipengaruhi oleh nutrisi lain yang terkandung dalam substrat diantaranya serat kasar, lemak kasar,kadar air, protein kasar dan kadar abu. Pada Gambar 5. dapat dilihat penurunan maupun kenaikan kadar BETN.

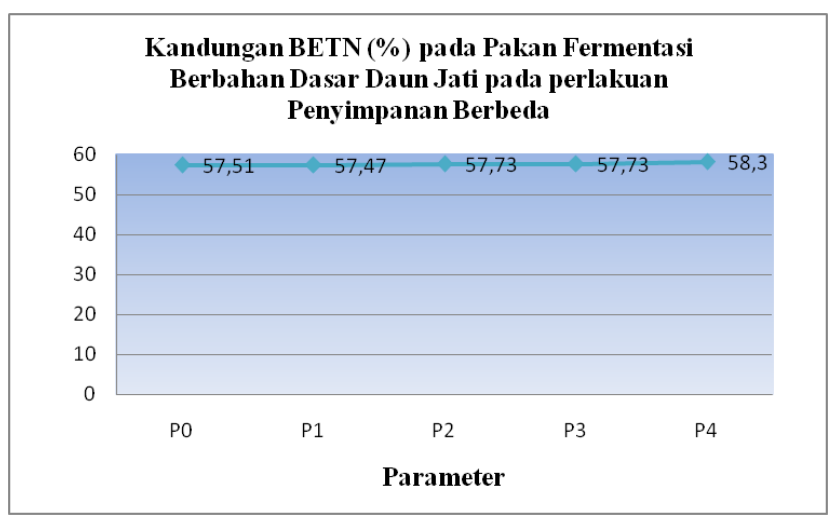

Gambar 5. Grafik Kadar BETN pada Tiap Perlakuan

\section{Kesimpulan}

Hasil penelitian menunjukkan bahwa lama penyimpanan pada pakan fermentasi berbahan dasar daun Jati memberikan hasil yang berbeda nyata terhadap perubahan kadar Bahan kering dan Serat kasar tetapi tidak berbeda secara nyata terhadap kadar Protein kasar, lemak kadar dan BETN pakan. Kesimpulan yang dapat diambil dari penelitian ini yatu, lama penyimpanan terbaik untuk mendapatkan nutrisi yang lebih optimal pada pakan fermentasi berbahan dasar daun Jati yaitu pada perlakuan P1 (penyimpanan 2 minggu) dengan kadar nutrisi yaitu Bahan kering 49.83, Lemak kasar 6.17, Serat kasar 19.28, Protein kasar 10.19, dan BETN 57.47.

\section{Daftar Pustaka}

Amaliah, Reski, Syahriani Syahrir, and Asmuddin Natsir. 2019. "Nutrition Content of White Teak-Based Complete Ration Formulated on As Feed Basis in Different Periods of Storage." International Journal of Current innovations in Advance Research 2(4): 58-63

Agustono, A.S, Widodo dan W. Paramita. 2010. "Kandungan Protein Kasar dan Serat Kasar pada Daun Kangkung Air (Ipomoea aquatica) yang Difermentasi" Jurnal Ilmiah Perikanan dan Kelautan 2(1): 37-43

Anwar, K., M.F. Rangga, P., H. Kifli., I. M. Ridha., P.P. Lestari., \& H. Wulandari. 2008. "Kombinasi Limbah Pertanian dan Peternakan 
Sebagai Alternatif Pembuatan Pupuk Organik Cair Melalui Proses Fermentasi Anaerob." Prosiding seminar National Teknoin Bidang Teknik Kimia. 95-100.

Aro, S. O. 2008. "Improvement in the Nutritive Quality of Cassava and Its By-Products throught Microbial Fermentation. "African Journal of Biotechnology" 7(25): 4789-4797

Fardiaz, S. 1992. Mikrobiologi Pakan. Jakarta : PT. Gramedia Pustaka Utama.

Hafizh, T. Wajizah, S. Samadi, S. 2016. "Evaluasi Kualitas Nutrisi Complete Feed Fermentasi Berbahan Dasar Ampas Sagu dengan Lama Pemeraman yang Berbeda." Universitas Syiah Kuala Darussalam.

Hamdat, N.H. 2010. "Pengaruh Lama Fermentasi Menggunakan Rhizopus Oryzae Terhadap Protein Kasar Ampas Sagu (Metroxilon rumphii).” Institut Pertanian Bogor

Muwakhid, B. 2011. "Potensi Limbah Hasil Pemangkasan Ranting gemblina Sebagai Pakan Ternak." Prosiding Seminar Nasional. Malang.

Rohmawati, D., Djunaidi, I.H. \& Widodo, E. 2015. "Nilai Nutrisi Tepung Kulit Ari Kedelai dengan Level Inokulum Ragi Tempe dan Waktu Inkubasi Berbeda." Jurnal Ternak Tropika 16(1): 30-33.

Surono, M. Soejono, S. Budhi, S,P. 2003. "Kecernaan Bahan Kering dan Bahan Organik In Vitro Rumput Gajah pada Umur Potong dan Level Aditif yang Berbeda." Jurnal Pengembangan Peternakan Tropis 28(4): 204-210

Syahrir, S. 2016. "Nilai Nutrisi Pakan Berbahan Jerami Padi, Gamal dan Urea Mineral Molases Liquid (UMML) Dengan Preparasi yang Berbeda." Buletin Nutrisi dan Makana Ternak 12(2): 78-82.

Sutardi, T. 2006. "Landasan Ilmu Nutrisi Jilid 1." Departemen Ilmu Makanan Ternak. Institut Pertanian Bogor

Tilman. A. D,. H. Hartadi., S. Reksohadiprodjo., S. Prawirokusumo dan S. Lebdosoekojo. 1998. Ilmu Ternak Dasar. Yogyakarta: Gajah Mada University Press.

Yunianta and Hartatik. 2015. "The Use of Trichoderma Sp. As a Starter of Fermentation Dry Teak Leaves (Tectona grandis) as Animal Feed." The 6th International Seminar on tropical Animal Production Integrated Approach in Developing Sustainable Tropical Animal Production. Yogyakarta. 291-295

Zheng, Y., M. Yates, H. Aung, S. Cheng, Y., C. Yu, H. Guo, R. Zhang, J, Vanderghevns and M. Jenkins, B. 2011. "Influence of Moisture Content on Microbial Activity and Silage Quality During Ensilage of Food Processing Residues”. Bioprocess Biosystems Engineering 34(8): 987995 